\title{
REVIEW \\ RECENT APPROACHES FOR THE SYNTHESIS OF HYBRID RESVERATROL MOLECULES AND THEIR BIOLOGICAL ACTIVITIES: A REVIEW
}

\author{
NOOR UL AMIN MOHSIN AND MUHAMMAD IRFAN
}

${ }^{1}$ Department of Pharmaceutical Chemistry, Faculty of Pharmaceutical Sciences, Government College University Faisalabad 38000, Pakistan

${ }^{2}$ Department of Pharmaceutics, Faculty of Pharmaceutical Sciences, Government College University Faisalabad 38000, Pakistan

Resveratrol (RSV) is a polyphenol produced by different plant species having a variety of biological activities. Synthesis of hybrid molecules of RSV with different natural and synthetic compounds has been studied. These hybrid molecules have been prepared by using fused or merged techniques or by using some linker groups. Wittig method was mostly applied by using the appropriate ylides to prepare the RSV core. The hybrid molecules prepared by these techniques exhibited anticancer, anti-inflammatory, antioxidant, anti-alzheimer, metal chelating and enzyme inhibitory activities. These hybrid RSV molecules can serve as a lead compounds for the future design of new drug molecules.

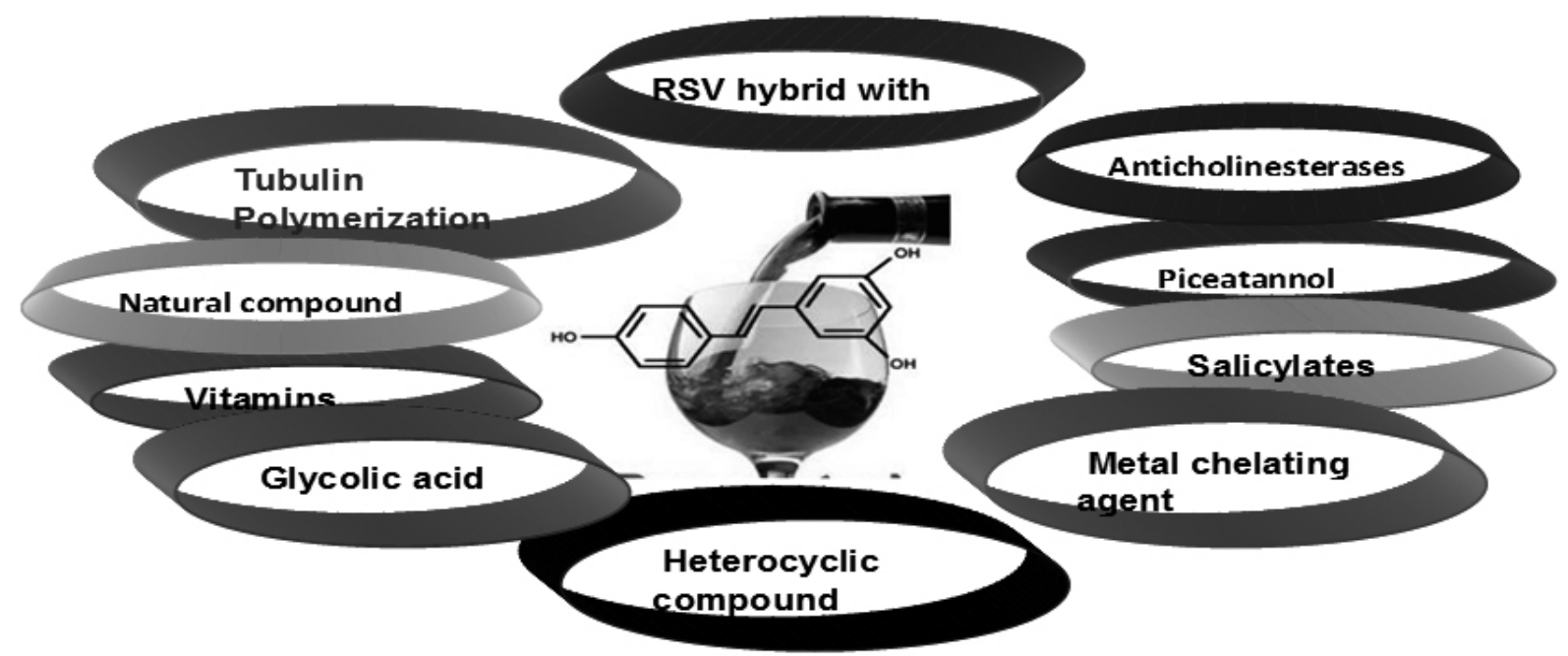

Key Words : Resveratrol (RSV), Wittig reaction, aldol condensation, natural molecules, antitumor activity, anti-Alzheimer activity

\section{INTRODUCTION}

Resveratrol (RSV) is a naturally occurring polyphenol produced by different plant species and possesses a wide variety of biological activities. It is present in different types of food and beverages such as mulberries, peanuts, grapes, apples, plums and red wine ${ }^{1}$. It is produced by plants as a protective substance to avoid the environmental or insect damage ${ }^{2}$. RSV has two stereoisomeric forms i.e. cis and trans. Trans isomer is most abundant and biologically active ${ }^{3}$. RSV influences many systems in the body and is therefore considered as a multitarget molecule ${ }^{4}$. RSV exhibited anti-inflammatory, anticancer, antioxidant, cardioprotective and chemopreventive properties ${ }^{5-9}$. It inhibits the proliferation of cancer cells without causing toxicity to normal cells $^{10}$. RSV is a hydrophilic molecule containing three hydroxyl groups (Figure 1) and it half life is only $8-14$ minutes which affects its bioavailability and efficacy ${ }^{1-13}$. Current modifications in the RSV deal with the improvement of pharmacokinetic properties in addition to the improvement of pharmacological activities. Different types of methods have been adopted to produce the RSV derivatives with different types of activities. Design of hybrid molecules comprising two pharmacophores in one molecule has gained much attention recently ${ }^{14,15}$. The hybrid molecules are classified as linked, merged and fused hybrid depending upon the incorporation of starting molecules ${ }^{16}$. RSV has also been combined with other biologically active compounds by using hybrid molecular techniques. These hybrid molecules of RSV demonstrated multiple activities. In the present review, we tried to summarize the synthetic routes used for the hybrid RSV molecules and biological activities exhibited by them.

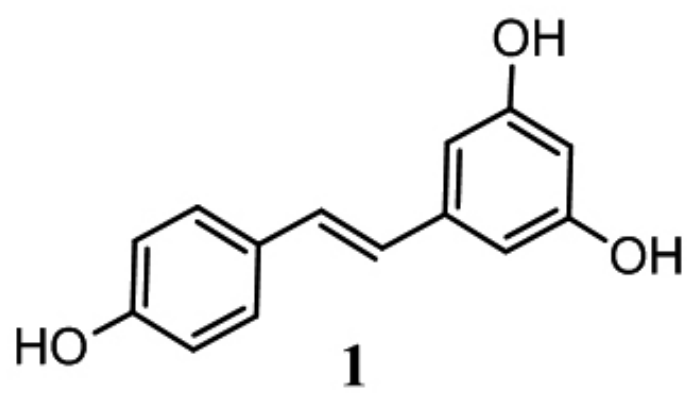

Figure 1: Trans Resveratrol.

2. Synthetic reactions and biological activities

2.1 RSV hybrid molecules with other natural compounds

Hybrid molecules of RSV have been prepared by the attachment with bioactive natural compounds like coumarin, chalcone and caffeic acid. Coumarin and RSV hybrid molecules were synthesized as an antioxidant agent. The starting material 2-hydroxy-4-acetoxy benzaldehyde (2) was reacted with 3-acetoxy phenyl acetic acid (3) in acetic anhydride by reflux for $16 \mathrm{hrs}$ (Scheme 1). After the first step, there is the formation of acetoxy-3phenyl coumarin (4). The final compound hydroxy-3-phenyl coumarin (5) was obtained by the process of hydrolysis in $90-94 \%$ yield. Compound 5 was the most active antioxidant ( $54 \%$ as a scavenger of hydroxyl free radicals) in this series. The presence of two hydroxyl groups in the molecule is optimal for the activity of the molecule. Therefore it can act as an inhibitor of over production of free radical ${ }^{17}$. 
<smiles>COc1cccc(CC(=O)OCCCC(=O)Oc2cccc(C=O)c2)c1</smiles><smiles>CC(C)OC1CCCCC1</smiles>

Scheme 1: Synthesis of rsv AND coumarin hybrids.

Design and synthesis of RSV and coumarin hybrid molecules were carried out as antitumor agents. Methyl substituted phenol (6) was used as a starting material which under goes duff reaction with hexamine in glycerol and boric acid at $150-160{ }^{\circ} \mathrm{C}$ to produce the compound 7 (Scheme 2). Reaction with phenyl acetyl chloride (8) in the presence of triethylamine and acetic anhydride produced compound $\mathbf{9}$. In the next reaction $\mathbf{1 0}$ was produced by bromination of compound $\mathbf{9}$ followed by formylation with hexamine to yield 11. Final compound 13 was synthesized by treatment of $\mathbf{1 1}$ with phosphorous ylides $\mathbf{1 2}$
After the synthesis, compounds were separated into $\mathrm{E}$ and $\mathrm{Z}$ isomer by column chromatography. These compounds showed stereospecificity because trans stereoisomers were more active as compared to cis isomer. MCF-7, HCT-28 and K-562 tumor cell lines were used for the anticancer evaluation of these compounds. Compound $\mathbf{1 3}$ was most potent against MCF-7 cell line having an $\mathrm{IC}_{50}$ value of $4.23 \mu \mathrm{mol}$. Compound $\mathbf{1 4}$ which is produced by using phenyl acetyl chloride in place of compound $\mathbf{8}$ showed prominent activity against HCT-28 having $\mathrm{IC}_{50}$ value of $3.78 \mu \mathrm{mol}^{18}$.<smiles>Cc1ccc(O)cc1</smiles>

6<smiles>COc1ccc(CC(=O)Cl)cc1OC</smiles>

7<smiles>COc1ccc(-c2cc3cc(C)ccc3oc2=O)cc1OC</smiles>

n-bromo succinimide reflux<smiles>COc1ccc(C[PbH2])cc1</smiles><smiles>COc1ccc(-c2cc3cc(C=O)ccc3oc2=O)cc1OC</smiles>

12

11<smiles>COc1ccc(-c2cc3cc(C)ccc3oc2=O)cc1OC</smiles>

10<smiles>COC(C)=O</smiles>

13

Scheme 2: Syntesis of RSV and coumarin hybrids. 
<smiles>CCOC(=O)C(C(=O)OCC)c1cc(OC)cc(OC)c1</smiles>

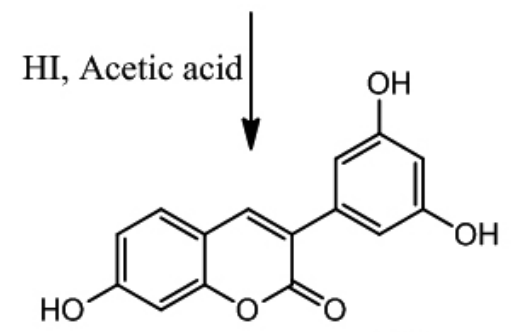

Scheme 3: Syntesis of RSV and coumarin hybrids.

Coumarin and RSV hybrid molecules were synthesized in which 3,4-double bond of coumarin was equivalent to the double bond of RSV. 3-Phenyl coumarin was synthesized by the reaction of resorcinol (15) with ethyl-3(3,5-dimethoxyphenyl) oxopropanoate (16) by Pechman reaction in $12 \mathrm{M}$ sulfuric acid to give intermediate product $17^{19}$. Hydrolysis of methyl group produced compound 18 in a 67\% yield (Scheme 3). Upon evaluation for vasorelaxant and antiplatelet aggregation activities, compound $\mathbf{1 8}$ was found to be potent vasorelaxant having $\mathrm{IC}_{50}$ value of $10.55 \pm 0.73 \mu \mathrm{M}$. It also displayed prominent activity as platelet aggregation inhibitor having $\mathrm{IC}_{50}$ value of $30.10 \pm$ $1.1 \mu \mathrm{M}$. It contains three hydroxyl group attached to the main core. Derivatives having hydroxyl group showed more activity than compound having methoxy group ${ }^{20}$.

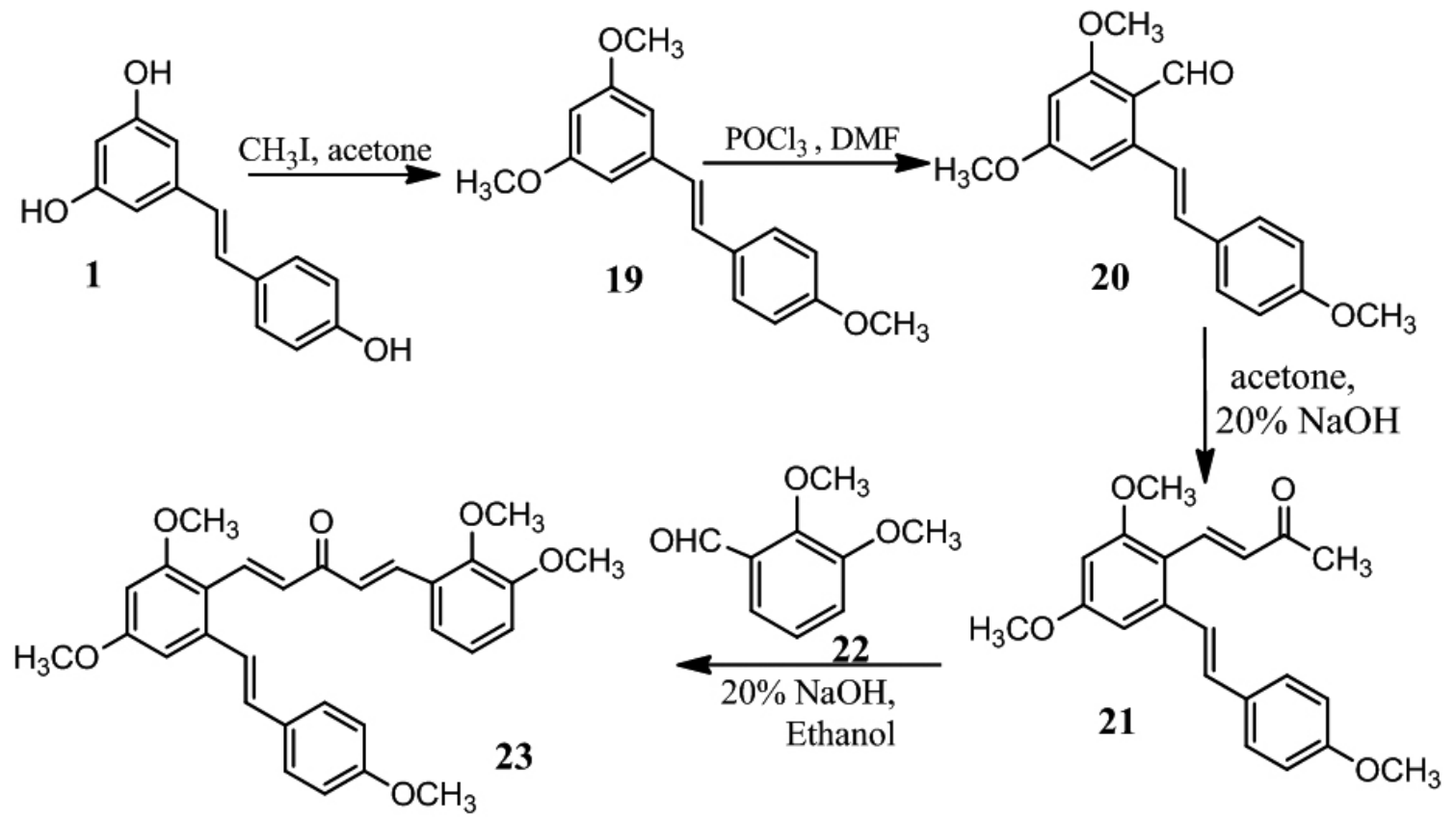

Scheme 4: Syntesis od RSV and curcumin hybrids.

RSV and curcumin hybrid molecules were synthesized as the antiinflammatory agents. Synthesis starts by methylation of RSV (1) with methyl iodide (Scheme 4) followed by Vilsmier reaction by using phosphorous oxychloride and DMF to produce compound $20^{21}$. Compound $\mathbf{2 0}$ was condensed with acetone to yield compound $\mathbf{2 1}$ which was reacted with 2,3-dimethoxy benzaldehyde (22) to produce the final hybrid compound $\mathbf{2 3}$ in yield of $72.3 \%$. Most of the compounds in this series exhibited the inhibition of lipopolysaccharide (LPS) induced production of TNF $\alpha$ and IL-6 but 23 displayed excellent anti-inflammatory activities. This compound also inhibited the lung injury caused by LPS in mice and showed less in vitro cytotoxicity ${ }^{22}$.

Hybrid RSV and chalcones were synthesized as anticancer agents.
P-methyl benzaldehyde (24) was condensed with p-methoxy acetophenone (25) by using sodium hydroxide as catalyst. $\alpha, \beta$-unsaturated carbonyl compound (26) is obtained (Scheme 5). Methyl group was converted into bromomethyl by reacting with $\mathrm{n}$-bromosuccinimide. Compound 27 having bromo methyl group was converted to Wittig salts $(\mathbf{2 8})$ by reaction with triphenyl phosphine. The Wittig salt was reacted with 3,4,5-trimethoxy benzaldehyde (29) in the presence of sodium hydroxide to yield trans stilbene (30) which was purified by column chromatography (55\% yield). Compound $\mathbf{3 0}$ showed the highest activity against leukemia SR $\left(\mathrm{GI}_{50} 1.98 \mu \mathrm{M}\right)$, non small lung cancer HOP-62 $\left(\mathrm{GI}_{50} 1.28 \mu \mathrm{M}\right)$, melanoma SK-MEL-2 $\left(\mathrm{GI}_{50} 1.89 \mu \mathrm{M}\right)$ and breast cancer MCF$7\left(\mathrm{GI}_{50} 2.18 \mu \mathrm{M}\right)$ cell lines. A strong hydrogen bonding was observed with the cysteine-241 amino acid in the binding pocket of colchicine-tubulin ${ }^{23}$. 


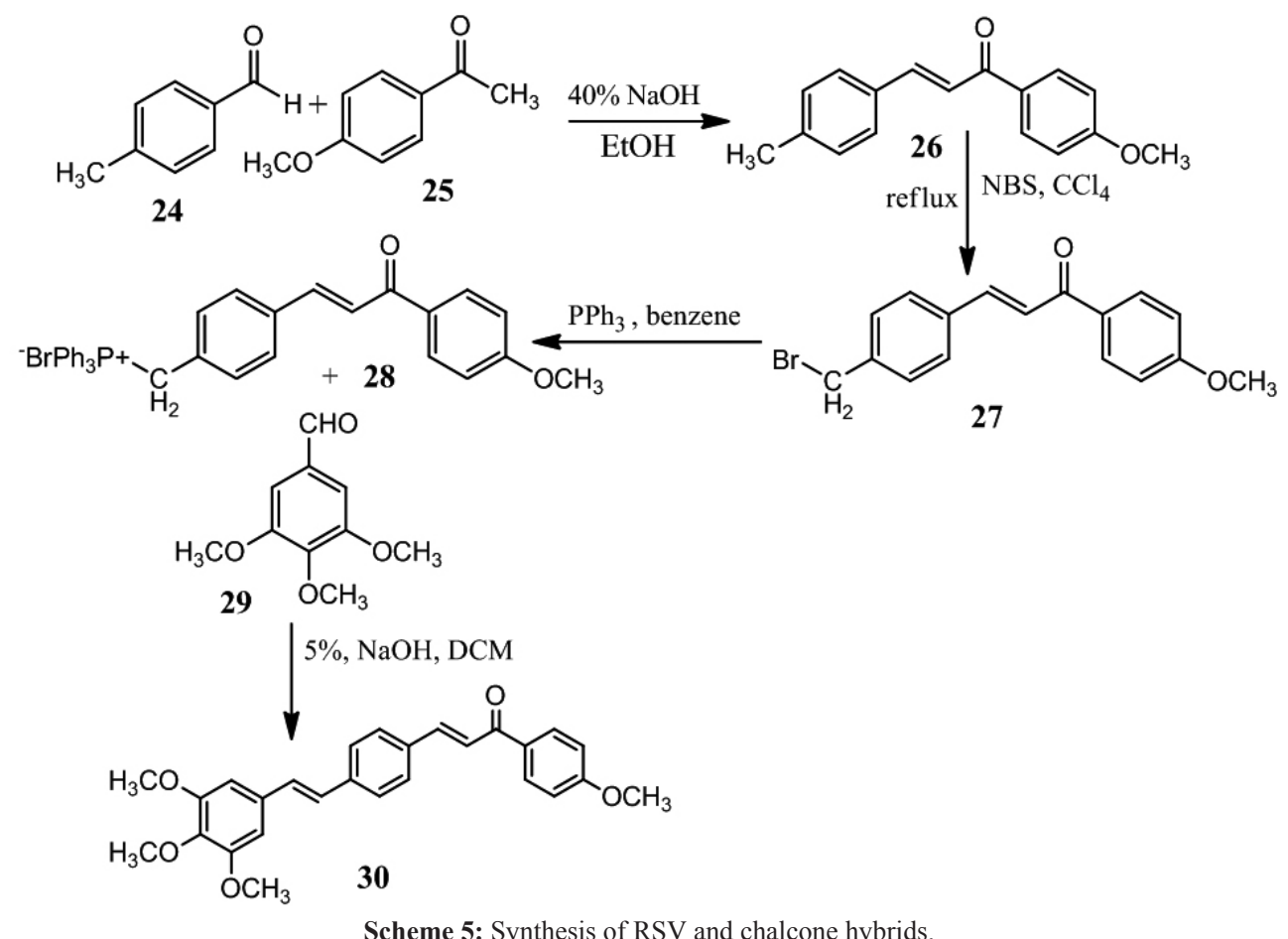

Design, synthesis and anti-inflammatory activity evaluation of aza-RSV chalcone compounds were carried out. 4-Methoxy acetophenone (25) was used as a starting material (Scheme 6). The process of nitration was carried out in the presence of nitric acid and concentrated sulfuric acid to produce the compound 31. Nitro group was reduced in the presence of $\mathrm{Pd} / \mathrm{C}$ catalyst to yield the aniline derivative 32. It was followed by aldol condensation with aromatic aldehyde
(29) to produce 33. Reaction with 2,3-dihydroxy benzaldehyde (34) produced compound 35 in $66 \%$ yield. Most of the derivatives in this series showed the inhibition of IL- 6 and TNF- $\alpha$ expression stimulated by LPS but $\mathbf{3 5}$ was the most potent $\left(\mathrm{IC}_{50} 1.8 \mu \mathrm{M}\right)$ inhibitor of IL-6 expression. 35 also displayed significant anti-inflammatory activity upon in vivo evaluation. The compounds in this series showed less toxicity to normal hepatic cell line ${ }^{24}$.<smiles>COc1ccc(C(C)=O)cc1</smiles><smiles>COc1ccc(C(=O)/C=C/c2cc(OC)c(O)c(OC)c2)cc1/N=C/c1cccc(O)c1O</smiles>

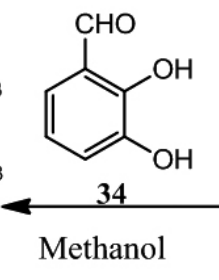

Methanol<smiles>COc1ccc(C(C)=O)cc1N(CC(=O)C=Cc1cc(OC)c(OC)c(OC)c1)C(=O)O[N+](=O)[O-]</smiles>

33

Scheme 6: Synthesis of aza RSV and chalcone hybrids.

RSV and caffeic acid hybrids were synthesized and evaluated for the anticancer activity. 4-nitro benzyl bromide (36) was converted into phosphonic acid precursor by Arbuzov reaction ${ }^{25}$. The compound $\mathbf{3 7}$ was further reacted with 3,5-dimethoxy benzaldehyde (38) to produce compound 39 (Scheme 7). Reduction of nitro group was carried out by tin chloride dihydrate under nitrogen and compound $\mathbf{4 0}$ was obtained. Caffeic acid derivatives 41 \& 42 were reacted with intermediate product $\mathbf{4 0}$ to yield the final hybrid molecules $\mathbf{4 3}$ and $\mathbf{4 4}$. Compound $\mathbf{4 3}$ and $\mathbf{4 4}$ showed prominent antitumor activity against
HT-29 and MDA-MB-231 cell lines having an $\mathrm{IC}_{50}$ value of $0.96 \mu \mathrm{M}$ and 2.14 $\mu \mathrm{M}$ respectively. The introduction of electron withdrawing groups produced less active compounds as compared to electron donating groups. Upon in vivo evaluation, compound $\mathbf{4 4}$ was also found to be the inhibitor of tumor growth. Compound $\mathbf{4 4}$ was found to be inhibitor of acetylation and phosphorylation of STAT3 (signal transducer and activator of transcription 3). Molecular docking studies showed a strong binding of this compound with STAT3 ${ }^{26}$. 
<smiles>CCCCCc1cc(CBr)ccc1[N+](=O)[O-]</smiles>

36<smiles>CP(C)(=O)Cc1ccc([N+](=O)[O-])cc1</smiles>

37

\section{$-\mathrm{OC}_{2} \mathrm{H}_{5}$}

$\mathrm{OC}_{2} \mathrm{H}_{5}$

sodium methoxide

38

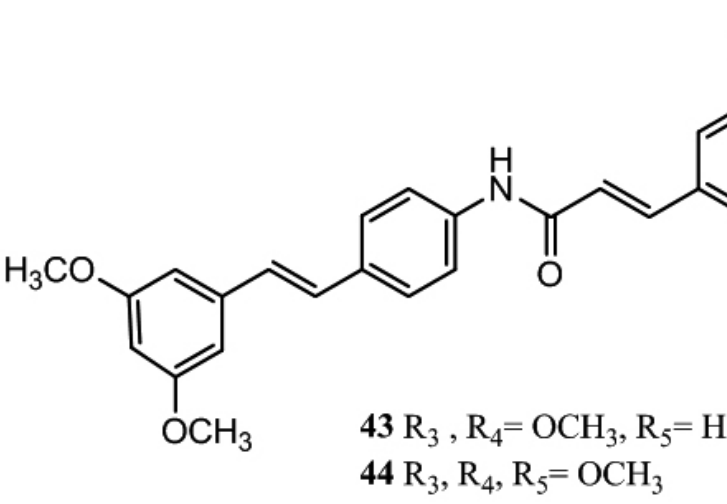

Scheme 7: Synthesis of RSV and caffeic acid hybrids.<smiles>COc1ccc(CPBr)cc1</smiles>

45<smiles>COC(=O)c1cc(C=O)ccc1OC</smiles>

46<smiles>COC(=O)c1cc(/C=C/c2ccc(OC)cc2)ccc1OC</smiles>

47

Scheme 8: Synthesis of RSV and salicylate hybrids.

\subsection{RSV and salicylates hybrid molecules}

Synthesis of hybrid molecules of RSV and salicylates was carried out and they were evaluated for their influence on cytochrome P1A1 (CYP1A1). Compound $\mathbf{4 7}$ was synthesized by Wittig reaction of compound 45 and 46 in the presence of dry tetrahydrofuran (THF) (Scheme 8). In order to obtain the $\mathrm{E}$ isomer, diphenyl disulfide was added after dissolving the product in the dry THF. The reaction mixture was stirred under the atmosphere of argon until $\mathrm{Z}$ isomer was converted to $\mathrm{E}$ isomer. Compound $\mathbf{4 7}$ showed inhibition of the CYP1A1 which is a sub type of cytochrome P450. It also showed the inhibition of CYP1A1 mRNA expression. Replacement of the methyl ester with the free carboxylic acid led to the formation of derivatives which showed the induction of CYP1A1 rather than inhibition ${ }^{27}$.

Hybrid molecules of RSV and salicylates were synthesized and evaluated for their activities as DNA-methyl transferases (DNMT3) inhibitor and cytotoxicity. In a $250 \mathrm{ml}$ three neck flask, 3,5-dimethoxy benzyl phosphonium bromide (48) and methyl 5-formyl-2-methoxy benzoate (46) were mixed in dry tetrahydrofuran to produce 49. Compound $\mathbf{4 9}$ (Scheme 9) and solution of boron tribromide were mixed after dissolving in dichloromethane to produce $\mathbf{5 0}$ in $69 \%$ yields. Compound $\mathbf{5 0}\left(\mathrm{IC}_{50} 25 \& 62 \mu \mathrm{M}\right)$ showed the prominent inhibition of DNMT3A and DNMT3B enzyme as compared to RSV. Compound $\mathbf{5 0}$ also exhibited antiproliferative activity against the HepG-2 and SK-BR-3 cell lines having $\mathrm{IC}_{50}$ value of 18.9 and $11.3 \mu \mathrm{M}$. Molecular docking studies showed a $\pi-\pi$ interaction with tryptophan amino acid of the DNMT3A and DNMT3B ${ }^{28}$. Compound $\mathbf{5 0}(20 \mathrm{mg} / \mathrm{kg})$ exhibited anti-inflammatory activity $(74 \%$ reduction of paw volume after $6 \mathrm{hrs})$ and was more selective for COX-2 $\left(\mathrm{IC}_{50} 1.0 \mu \mathrm{M}\right)$ as compared to COX-1 inhibition $\left(\mathrm{IC}_{50} 4.1 \mu \mathrm{M}\right)$. Compound $\mathbf{5 0}$ also showed a moderate level of free radical scavenging activity as it showed inhibition (33\%) of reactive oxygen species formation induced by hydrogen peroxide ${ }^{29}$.

\subsection{RSV hybrids with vitamins}

Hybrid molecules of RSV and pyridoxine were synthesized by using pyridoxine as a starting material (51). Chlorination of 5-hydroxy methyl group was carried out after protecting the 3 and 4 hydroxyl group and these two reactions produce compound 53 (Scheme 10). Compound 53 was reacted with tri-ethoxy phosphine to produce the phosphate derivative 54. Compound $\mathbf{5 4}$ underwent Wittig reaction with 3-hydroxy benzaldehyde to produce compound $\mathbf{5 5}$ which was deprotected to produce $\mathbf{5 6}$. The reaction of compound $\mathbf{5 5}$ with diethylamine and $\mathbf{5 6}$ with piperidine, morpholine produced compounds $\mathbf{5 8}$, 57a and 57b. Compound 58 and 57a exhibited acetyl cholinesterase inhibitory activity having $\mathrm{IC}_{50}$ values of $2.11 \pm 0.10 \mu \mathrm{M}$ and $1.56 \pm 0.20 \mu \mathrm{M}$ respectively. Compound 57b was found to be the potent inhibitor $\left(\mathrm{IC}_{50} 2.68 \pm 0.11 \mu \mathrm{M}\right)$ of monoamine oxidase $\mathrm{B}^{30}$. 
<smiles>COc1cc(C[Pb])cc(OC)c1</smiles>

48<smiles>COC(=O)c1cc(C=O)ccc1OC</smiles>

THF, n BuLi<smiles>COC(=O)c1cc(/C=C/c2cc(OC)cc(OC)c2)ccc1OC</smiles>

49<smiles>COC(=O)c1cc(/C=C/c2cc(O)cc(O)c2)ccc1O</smiles>

Scheme 9: Synthesis of RSV and salicylate hybrids.

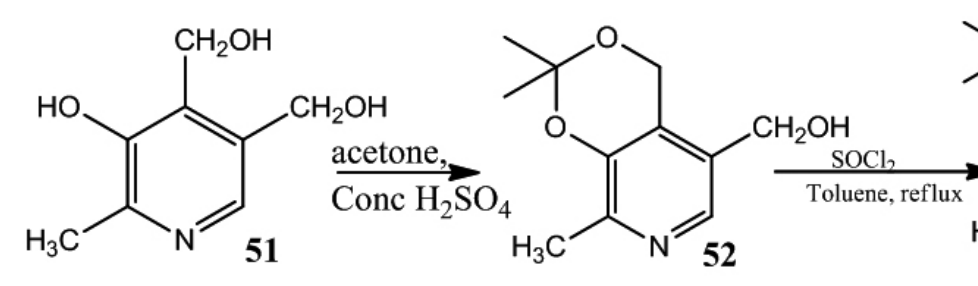<smiles>CCOCCNc1cc(CCl)c2c(c1C)OC(C)(C)OC2</smiles><smiles>[R]Cc1ccc(/C=C/c2cnc(C)c(O)c2CO)cc1O</smiles>

Scheme 10: Synthesis of RSV and pyridoxine hybrids. 
<smiles>Cc1cc(O)c(C)c(C)c1O</smiles>

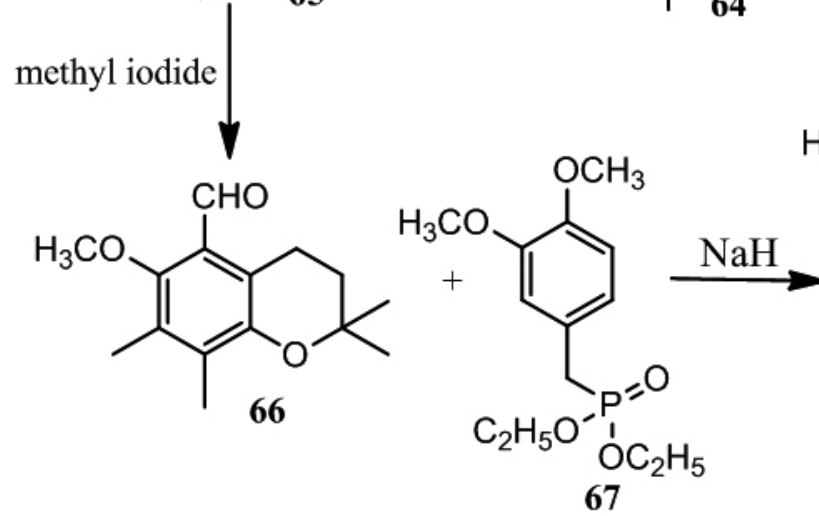<smiles>COc1ccc(/C=C/c2c3c(c(C)c(C)c2OC)OC(C)(C)CC3)cc1OC</smiles><smiles>Cc1cc(/C=C/c2c(O)c(C)c(C)c3c2CCC(C)(C)O3)ccc1O</smiles>

Scheme 11: Synthesis of RSV and vitamin E hybrids.

Hybrid molecules of RSV with chromone fragment of vitamin E were synthesized as a free radical scavenger. Coupling reaction of 2, 3, 5-trimethylbenzene-1, 4-diol (59) with 2-methylbut-3-en-2-ol (60) and cyclization reaction produced $2,2,5,7,8$-pentamethyl-6-hydroxycoumarin (61) (Scheme 11). This product undergoes bromination followed by protection of hydroxyl group. Oxidation of the product was carried out by n-methyl morpholine n-oxide to produce 64. Then deprotection of hydroxyl group was done with ammonium acetate followed by methylation with methyl iodide to produce compound 66. Wittig-Horner reaction of 66 with diethyl-3,4diemthoxy benzyl phosphonate $\mathbf{6 7}$ yields trans isomer methoxy hybrid $\mathbf{6 8}$ which was demethylated with ethyl sulfhydrate to produce the final hybrid compound 69 with 54\% yield. Hybrid molecules proved to be the better antioxidant than vitamin E and RSV alone. Compound 69 was most active scavenger of HNTTM [tris(2,4,6-trichloro-3,5-dinitrophenyl)methyl] free $\left(\mathrm{n}_{\text {HNTTM }} 4.29\right)$ radical $^{31}$.

2.4 RSV hybrid with heterocyclic compounds

Synthesis of RSV and phenyl sulfonyl furoxan hybrid molecules was reported by replacing the alkene in RSV by n-acyl hydrazones. Bis-aryl sulfonyl furoxan (70) and 4-hydroxy benzaldehyde (71) were condensed together by using dichloromethane as a solvent to produce the compound 72 (Scheme
12). The intermediate product (72) was reacted with p-hydroxy benzhydrazide (73) to get the n-acyl hydrazone derivative (74). The molecule showed nitric oxide releasing property. Compound $\mathbf{7 4}$ was found to be platelet aggregation inhibitor (87.1 $\pm 0.6 \%$ using ADP as an agonist) and showed antithrombotic effect. This compound showed less bleeding time than that of aspirin and upon in vivo evaluation exhibited protection against thromboembolism up to $80 \%$ as compared to aspirin which showed $40 \%$ protection ${ }^{32}$.

RSV and oxadiazole hybrid molecules were synthesized by the reaction of RSV bromide ( $75 \& 81)$ with 1,3,4-oxadiazole-2-thione $(\mathbf{8 6} \&$ 87) derivatives in the presence of potassium carbonate and using acetonitrile as a solvent. RSV bromide having amide and ester linkage $(\mathbf{7 5} \& \mathbf{8 1})$ were synthesized separately as shown in scheme 13 and 14. 1,3,4-oxadiazole-2-thione derivatives were synthesized by using carboxylic acid derivatives (82) as starting material as shown in scheme 15. Compound 89 and 91 exhibited prominent activities against SiHa, PANC-I and MDA-MB-231 cancer cell lines having $\mathrm{GI}_{50}$ values less than $0.1 \mu \mathrm{M}$. These compounds contain 3-trifluoromethyl phenyl group attached with oxadiazole. Compound $\mathbf{8 8}$ and $\mathbf{9 0}$ were also active having $\mathrm{GI}_{50}$ values less than $0.1 \mu \mathrm{M}$. These compounds contain fluorine atom at position \#2 of the phenyl group attached with oxadiazole. Therefore electron withdrawing groups at position \# 5 of 1,3,4-oxadiazole increased the antiproliferative activity ${ }^{33}$. 


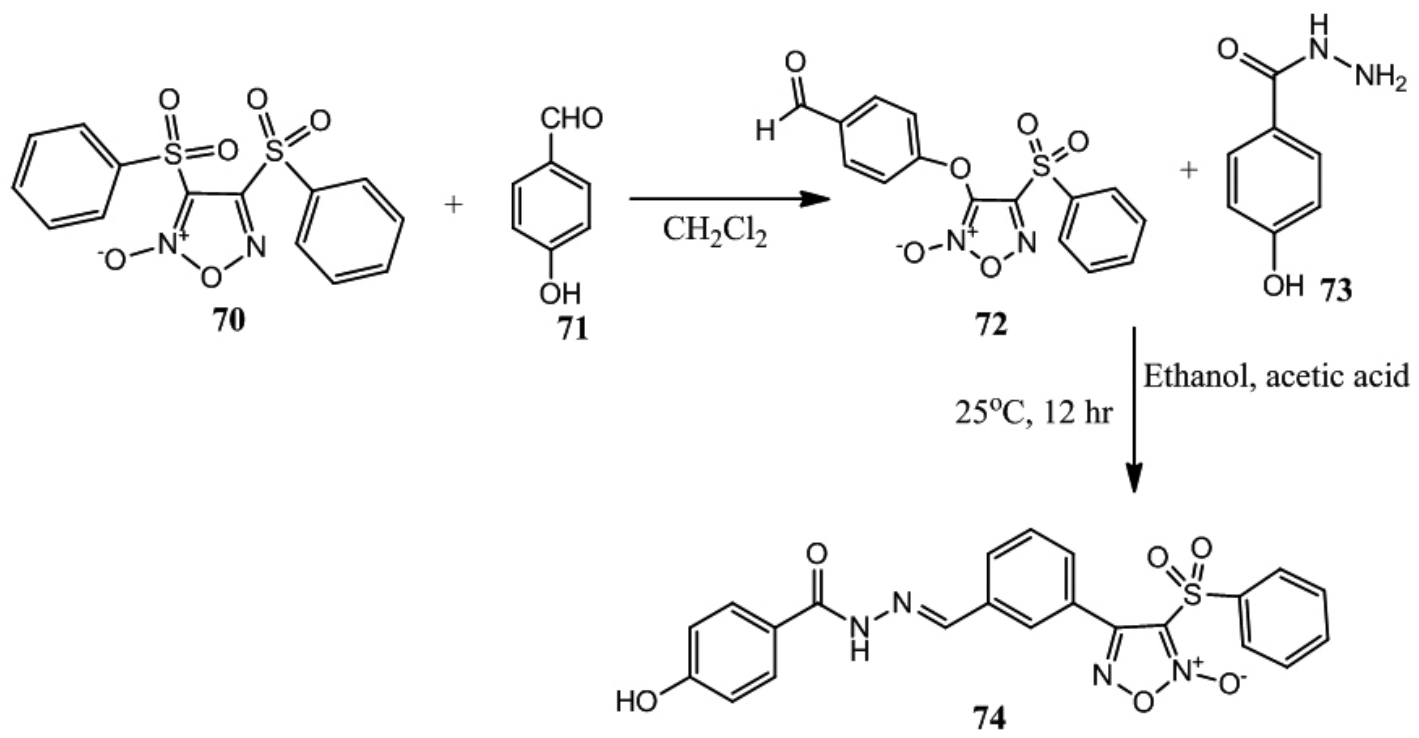

Scheme 12: Synthesis of RSV and Phenyl sulfonyl furaxon hybrids.<smiles>COc1cc(/C=C/c2ccc(NC(=O)CBr)cc2)cc(OC)c1</smiles>

Scheme 13: Synthesis of RSV bromide.

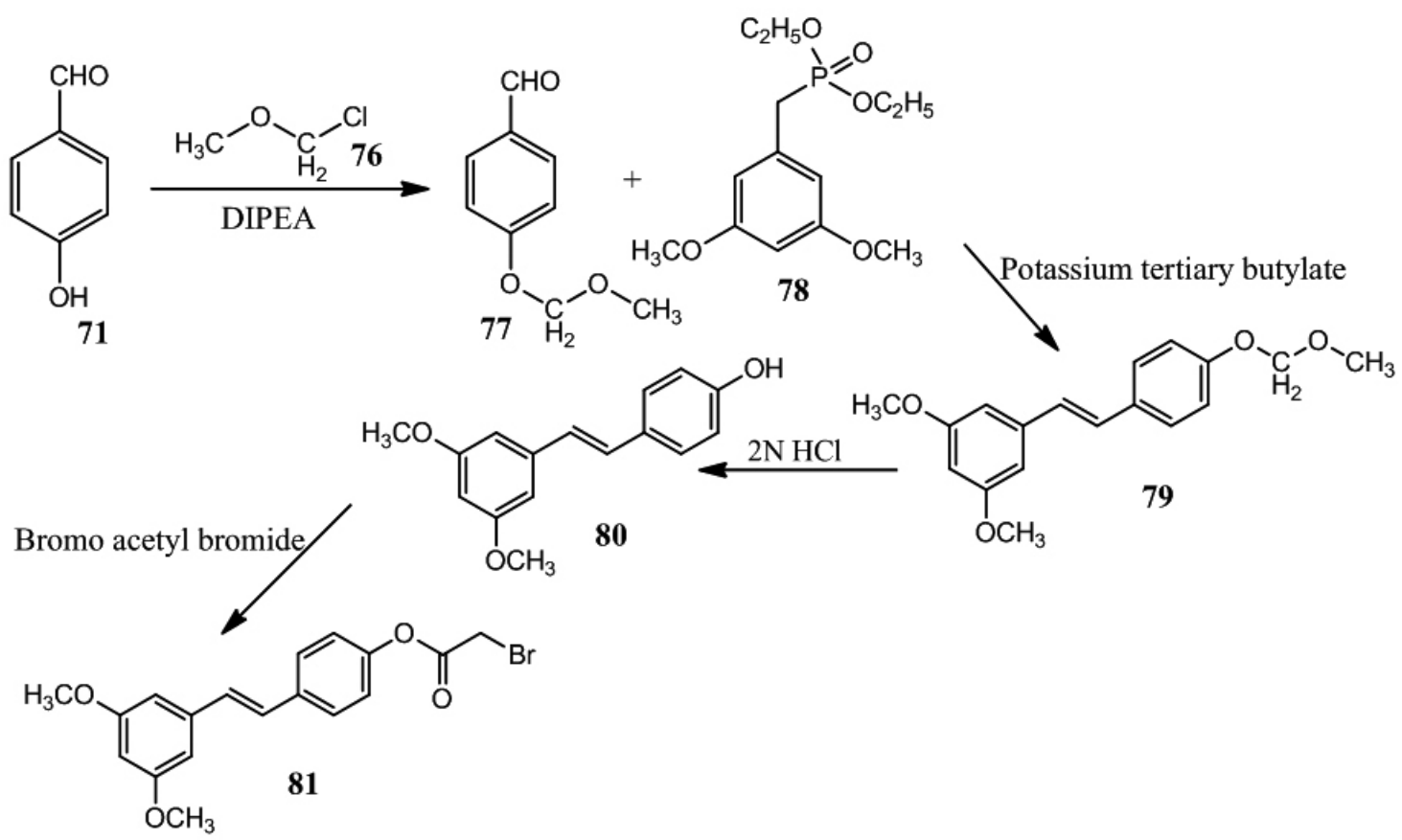

Scheme 14: Synthesis of RSV bromide. 
<smiles>[R]C(=O)NN</smiles>
carbon disulfide Potassium hydroxide ethanol

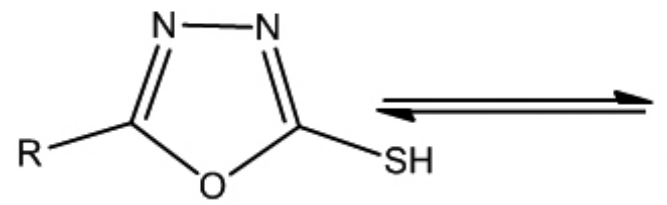

$86 \& 87$

Scheme 15: Synthesis of oxadiazole 2-thione.

$86 \& 87$<smiles>[R]c1nnc(SCC(=O)Nc2ccc(/C=C/c3cc(OC)cc(OC)c3)cc2)o1</smiles><smiles>[R]c1n[nH]c(=S)o1</smiles>

85

\section{$\mathrm{R}=3$-trifloromethyl \\ $\mathrm{R}=2$-floro phenyl}

$86 \mathrm{R}=2$-floro phenyl $87 \mathrm{R}=3$-trifloromethyl

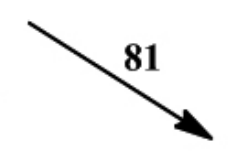<smiles>[R]c1nnc(SCC(=O)Oc2ccc(/C=C/c3cc(OC)cc(OC)c3)cc2)o1</smiles>

Scheme 16: Synthesis of RSV and oxadiazole hybrids.

2.5 RSV hybrid with anti cholinesterase

Hybrid molecules of RSV with tacrine were synthesized as anti-Alzheimer agents. Starting material (compound 39) was reduced with hydrogen and palladium/carbide to produce 40a (Scheme 17). The synthesis of compound 93 was carried out by the reaction of $40 a$ and 92 using microwave irradiation at $120^{\circ} \mathrm{C}$ for 1 hour. After the reaction, the flash chromatographic procedure was used to get the pure product using mobile phase of petroleum ether and ethyl acetate. Compound $\mathbf{9 3}$ was found to be the potent inhibitor $\left(\mathrm{IC}_{50} 0.8 \mu \mathrm{M}\right)$ of acetyl cholinesterase. The chlorine atom at position \# 6 is possibly involved in hydrophobic van der waals interaction to hydrophobic pocket of acetyl cholinesterase. Compound 94 displayed the prominent inhibition $(37.3 \pm 4.1 \%)$ of self- aggregation of $\mathrm{A} \beta_{42}{ }^{34}$.
Compound $\mathbf{4 0}$ is produced by the reduction of $\mathbf{3 9}$ with stannic chloride. (Scheme 18) Compound 95 was synthesized by coupling reaction of 40 and 92 in the presence of phenol. Compound 95 was treated with boron tribromide drop wise in dry dichloromethane under the atmosphere of nitrogen. The reaction was stirred at room temperature for $\mathbf{2 0}$ hours. After the reaction, compound 96 was purified by flash chromatography. Compound 96 also exhibited the inhibition $\left(\mathrm{IC}_{50} 8.8 \pm 0.4 \mu \mathrm{M}\right.$ ) of acetyl cholinesterase and self-aggregation $(31.2 \pm 9 \%)$ of $\mathrm{A} \beta_{42}{ }^{34}$. 
<smiles>COc1cc(CCc2ccc(N)cc2)cc(CCc2ccc(Nc3c4c(nc5cc(Cl)ccc35)CCCC4)cc2Nc2ccc(CCc3cc(O)cc(O)c3)cc2CCc2ccc(Nc3c4c(nc5cc(Cl)ccc35)CCCC4)cc2)c1</smiles>

Scheme 17: Synthesis of RSV and tacrine hybrids.

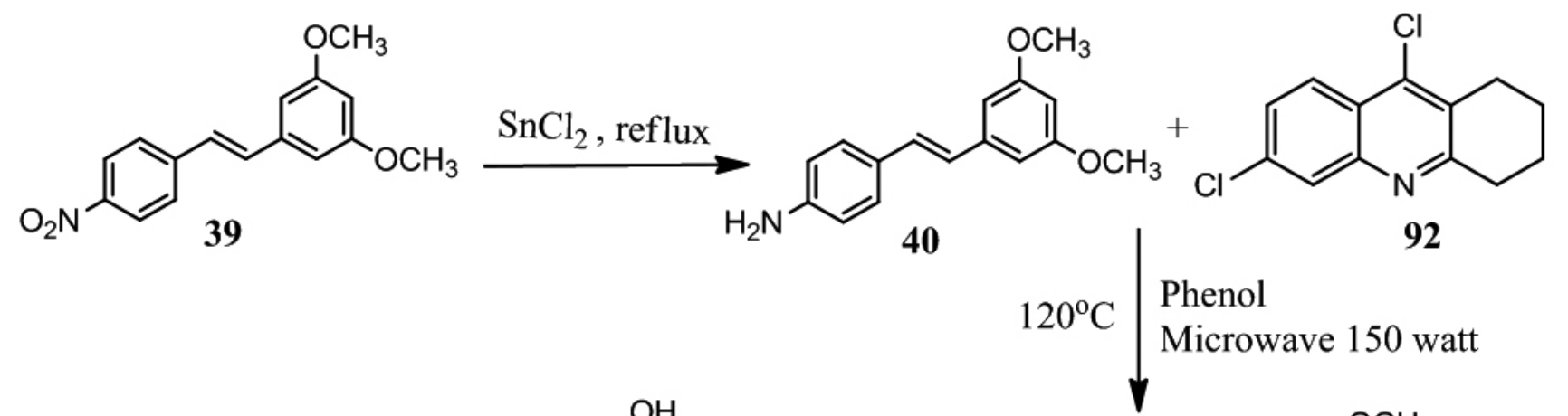<smiles>COc1cc(/C=C/c2ccc(Nc3c4c(nc5cc(Cl)ccc35)CCCC4)cc2)cc(/C=C/c2ccc(Nc3c4c(nc5cc(Cl)ccc35)CCCC4)cc2)c1</smiles>

Scheme 18: Synthesis of RSV and tacrine hybrids.

2.6 RSV hybrid molecules with metals chelating agents

Hybrids molecules were prepared by combining the pharmacophores of RSV and clioquinol as a potential metal chelator, antioxidant and inhibitors of beta amyloid (A $\beta$ ) aggregation. 4-Hydroxy benzaldehyde (71) was used as starting material which was protected with methoxy methyl group (77) (Scheme 19). 8-hydroxy quinoline (97) was reacted with formaldehyde and concentrated hydrochloric acid to produce $\mathbf{9 8}$. Compound 98 was reacted with triethyl phosphite followed by protection of hydroxyl group to give $\mathbf{9 9}$. Wittig reaction of 99 and 77 gave the intermediate product $\mathbf{1 0 0}$ which was deprotected with hydrochloric acid to produce the compound 101. Compound 101 was found to be the most potent inhibitor of $\mathrm{A} \beta$ aggregation $(71.69 \pm 2.42 \%)$.
Compound 101 also exhibited the metal chelating and antioxidant activity (oxygen radical absorbance capacity ORAC $2.18 \pm 0.12$ ). This compound was found to be non-toxic up to $2000 \mathrm{mg} / \mathrm{kg}$ body weight ${ }^{35}$.

RSV was attached with the pharmacophore of clioquinol to produce the new multitarget directed molecules. In order to synthesize these molecules 4-nitrobenzaldehyde (102) was used as a starting material (Scheme 20). It undergoes the process of reduction, bromination and reaction with triethyl phosphate to produce compound (103). Reaction with 3,5-dimethoxy benzaldehyde (38) in the presence of sodium ethoxide produced compound $\mathbf{3 9}$. Reduction of $\mathbf{3 9}$ in the presence of stannic chloride converted the nitro group 
into the amino group (40) which was reacted with 2-hydroxy benzaldehyde derivatives 104 to yield the $\mathbf{1 0 5}$. Demethylation reaction of 105 with boron tribromide in dichloromethane at $-20^{\circ} \mathrm{C}$ produced compound 106. Compounds 105 and 106 exhibited the inhibition of $A \beta$, fibril formation and copper induced
$A \beta$ aggregation. These compounds also showed binding capacities for copper $\mathrm{Cu}$ ) metals and antioxidant activities. MAO-B and cholinesterase inhibitory activities were also observed for these compounds. Due to these wide ranges of properties, they can serve as a potential lead compound for alzheimer disease ${ }^{36}$

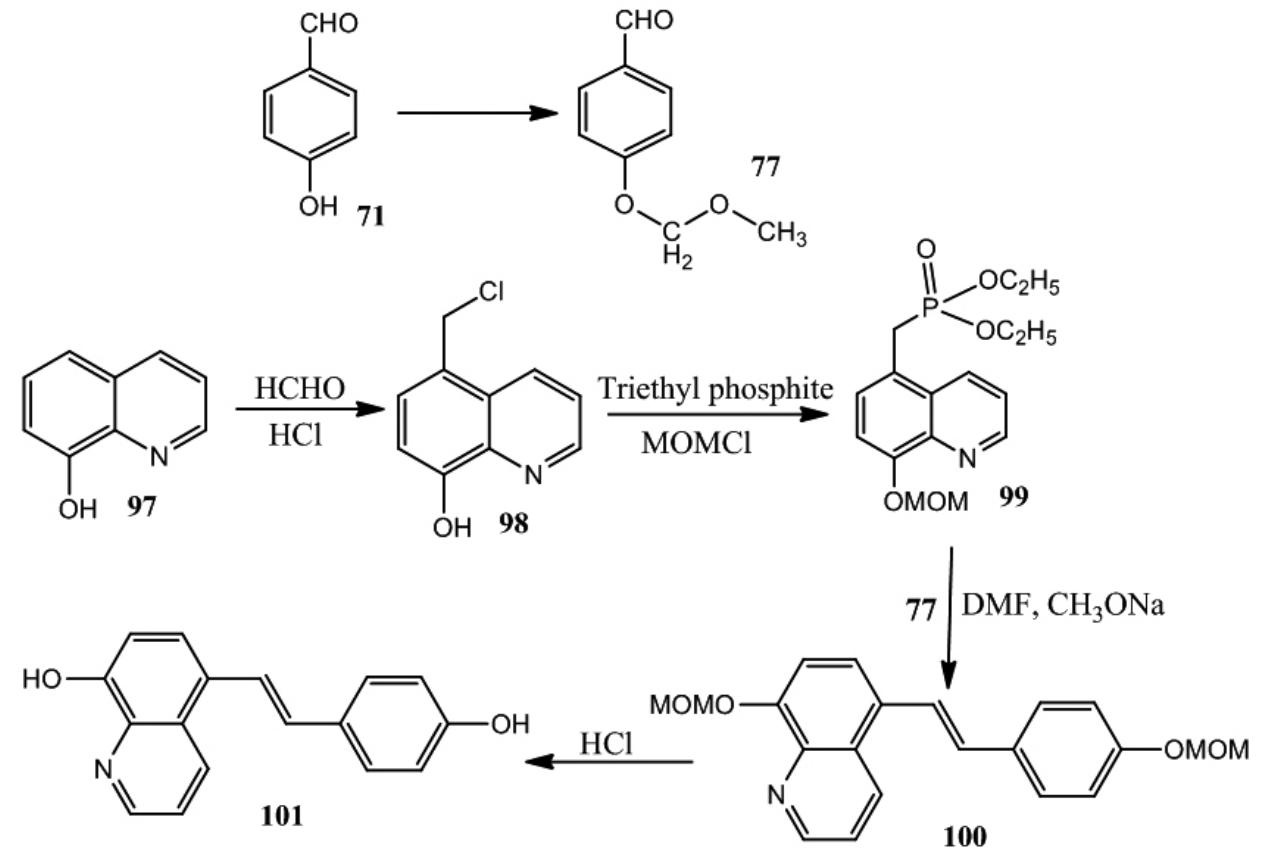

Scheme 19: Synthesis of RSV and clioquinol hybrid.<smiles>O=Cc1ccc([N+](=O)[O-])cc1</smiles><smiles>CCOP(=O)(Cc1ccc([N+](=O)[O-])cc1)OCC</smiles><smiles>CN(C)c1ccc(O)c(C=O)c1</smiles><smiles>CN(C)c1ccc(O)c(CNc2ccc(/C=C/c3cc(O)cc(O)c3)cc2)c1</smiles> 


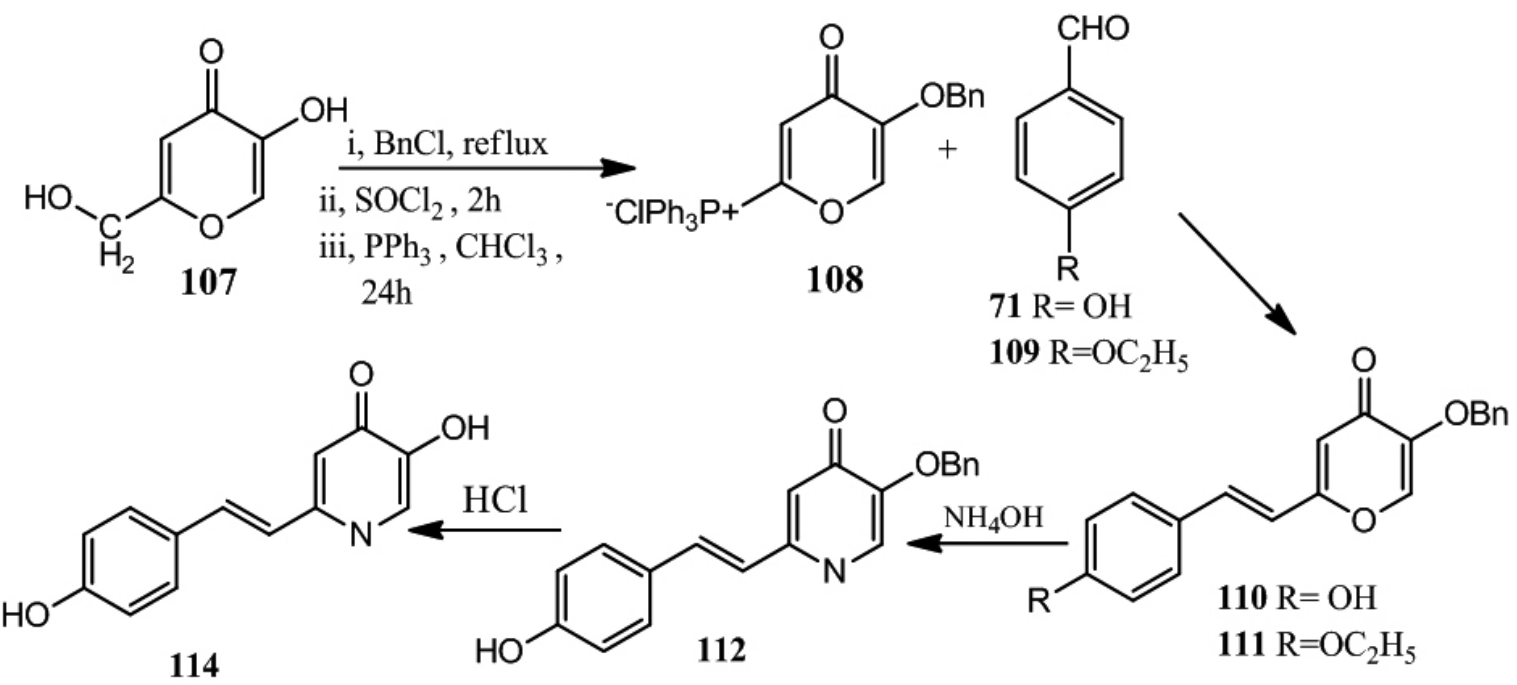

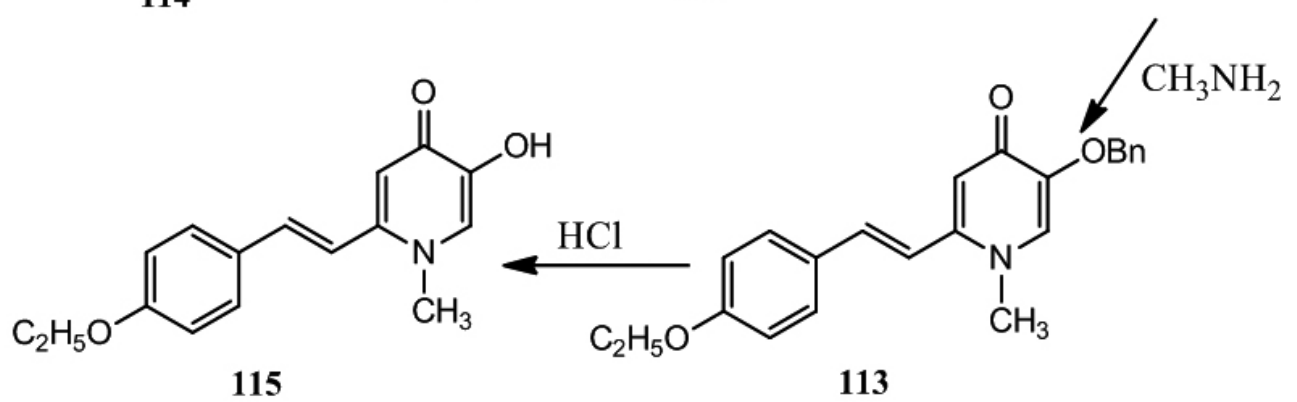

Scheme 21: Synthesis of RSV and deferiprone hybrid.

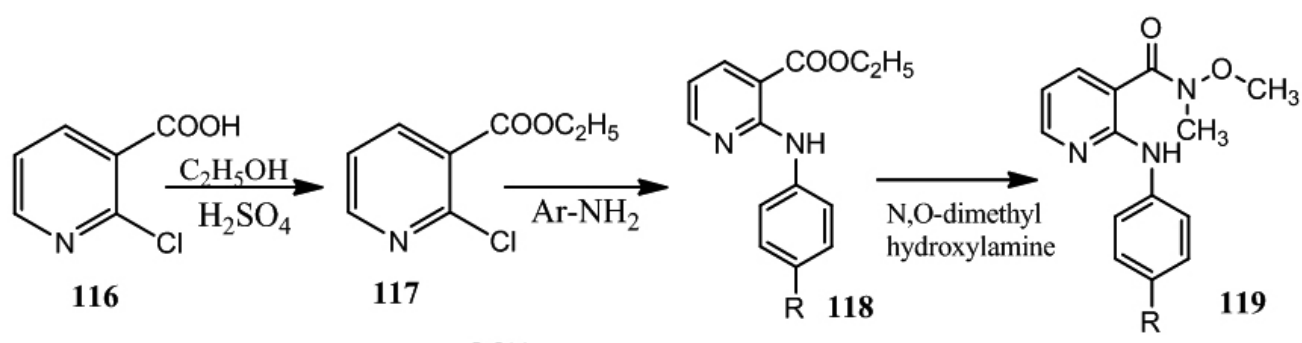<smiles>COc1cc(/C=C/c2cccnc2Nc2ccc(Cl)cc2)cc(OC)c1</smiles><smiles>COc1cc(C=PBr)cc(OC)c1</smiles>

$\mathrm{Cl}$

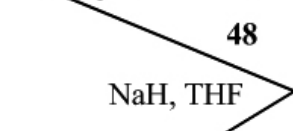<smiles>COc1cc(/C=C/c2cccnc2Nc2ccccc2)cc(OC)c1OC</smiles>

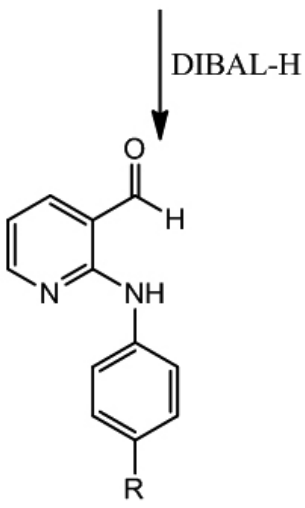


RSV and deferiprone hybrid molecules were synthesized as anti-alzheimer agents by using kojic acid (107) as a starting material which was treated with benzyl chloride, thionyl chloride and triphenylphosphine to produce the compound 108. Compound 108 (Scheme 21) was condensed with p-ethoxy and p-hydroxy benzaldehyde $(\mathbf{1 0 9} \& \mathbf{7 1})$ to produce compound $110 \& 111$. Compound 110 \& 111 were treated with ammonium hydroxide and methyl amine to yield $112 \& \mathbf{1 1 3}$. Finally, the benzyl protecting group was removed by treatment with hydrochloric acid and 114, 115 were achieved. Compound 114 and 115 exhibited prominent activities as beta amyloid $\left(A \beta_{1-42}\right)$ inhibitors having $\mathrm{IC}_{50}$ values of $10.72 \pm 0.5$ and $8.94 \pm 0.84 \mu \mathrm{M}$ respectively. Therefore the introduction of hydroxyl and alkoxy groups are important for the activity as $\mathrm{A} \beta$ inhibitors ${ }^{37}$

2.7 RSV hybrids with tubulin polymerization inhibitors

E7010 is an anilinopyridine sulphonamide derivative and it possesses the property of tubulin polymerization inhibition. RSV and E7010 hybrid molecules were synthesized by using 2-chloronicotinic acid (116) as starting material (Scheme 22). It undergoes esterification with ethanol in the presence of sulfuric acid to produce 2-chloro ethyl nicotinate (117). It was condensed with different substituted anilines in ethylene glycol to give ethyl 2-anilinonicotinate (118). It was converted into Weinreb amide (119) by using trimethyl aluminium and N,O-dimethyl hydroxylamine hydrochloride. Reduction of Weinreb amide with di-isobutyl aluminium hydride produced 2 -anilino nicotinaldehyde $(\mathbf{1 2 0}, \mathbf{1 2 1})$ in $70-90 \%$ yield. The final products 123 and 124 were synthesized by reaction with triphenyl phosphonium $(48 \& 122)$ salts with a yield of $92 / 8 \%(E / Z)$ and $90 / 10 \%(E / Z)$. Compounds $\mathbf{1 2 3}$ and 124 showed prominent antiproliferative activity ranging from $\mathrm{GI}_{50} 1.8-9.8 \mu \mathrm{M}$ against A-549, HepG-2, Hela and DU-145 cancer cell lines. These compounds were highly active against HepG2 cell lines having $\mathrm{GI}_{50}$ values of 2 and $3 \mu \mathrm{M}$. Upon further evaluation of $\mathbf{1 2 4}$ against cancer cell line of different origin, it showed $\mathrm{GI}_{50}$ values ranging from 1.0-16 $\mu \mathrm{M}$. These compounds showed the inhibition of tubulin protein and also cell cycle specificity ${ }^{38}$.

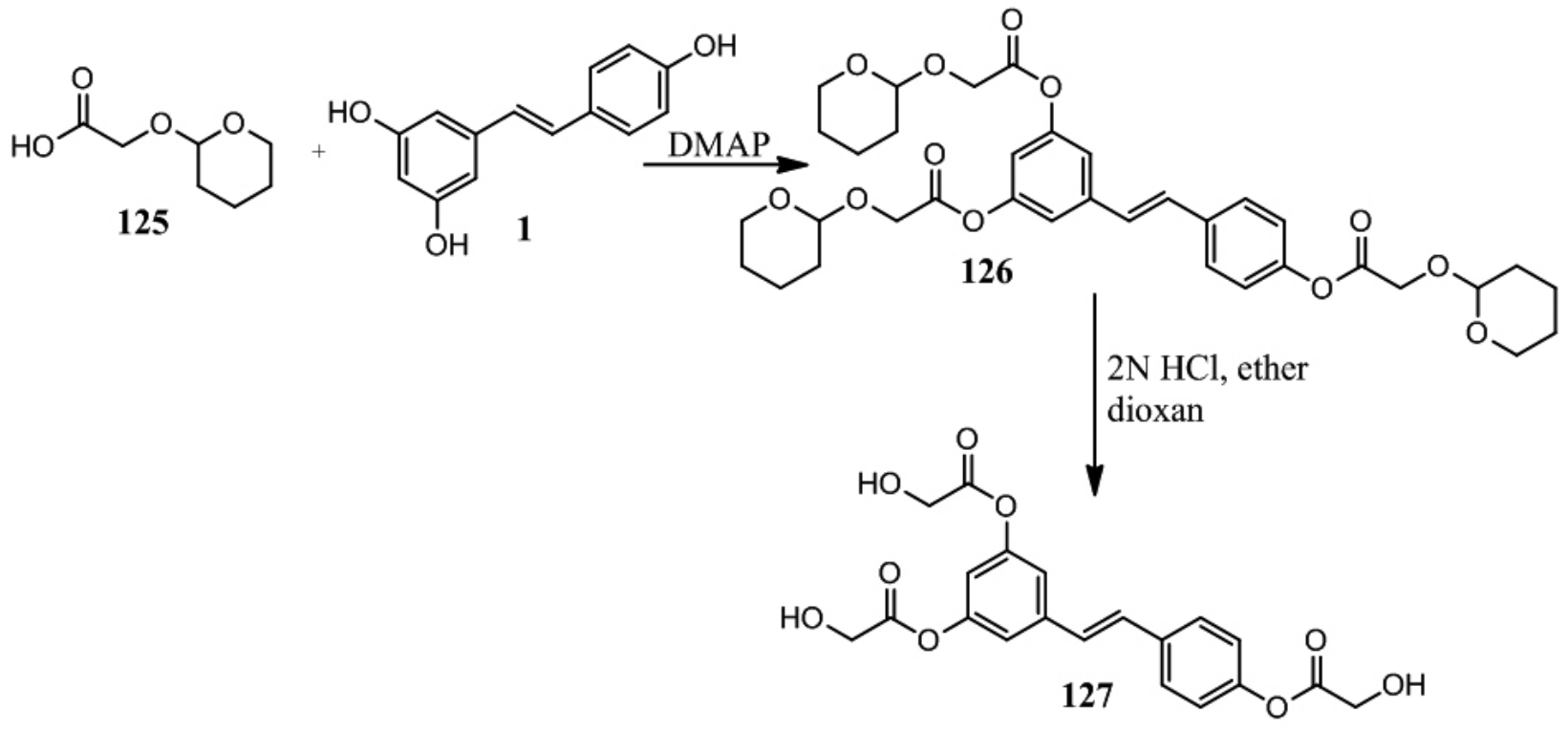

Scheme 23: Synthesis of RSV triglycolate.

2.8 RSV hybrid with glycolic acid

The hybrid RSV-glycolic acid molecule was synthesized by using pyran protected glycolic acid. Compound $\mathbf{1 2 5}$ was reacted with RSV (1) by using dimethyl amino pyridine (DMAP) as a catalyst to produce compound $\mathbf{1 2 6}$ (Scheme 23). Compound $\mathbf{1 2 6}$ was treated with $2 \mathrm{~N}$ hydrochloric acid in ether to yield the RSV triglycolae 127. Upon evaluation for the anti-melanogenic activity, hybrid RSV triglycolate (RTG) molecule was found to be the potent inhibitor of melanin synthesis in murine melanoma B16/F10 and HEM (human epidermal melanocyte) cell culture. The new molecule also inhibited the tyrosine enzyme. Compound $\mathbf{1 2 7}$ showed comparable cytotoxicity as that of
RSV and RSV triacetate. Therefore RTG has the potential of being used in cosmaceutical product as a skin whitener ${ }^{39}$.

\subsection{RSV and piceatannol hybrid}

Synthesis of RSV and piceatannol hybrid molecules was carried out in which 3-hydroxy-2-iodo-4-methoxy benzaldehyde (128) was used as starting material (Scheme 24). It was converted into 2-aryl benzofuran derivative (129) by Sonogashira cyclization reaction ${ }^{40}$. Compound 129 undergoes halogenation, Suzuki coupling to install 3-aryl group followed by Wittig Horner reaction to produce the compound (130) in $27 \%$ yield. Boron tribromide mediated demethylation of compound $\mathbf{1 3 0}$ yielded compound $\mathbf{1 3 1}$ in $61 \%$ yield ${ }^{41}$. 


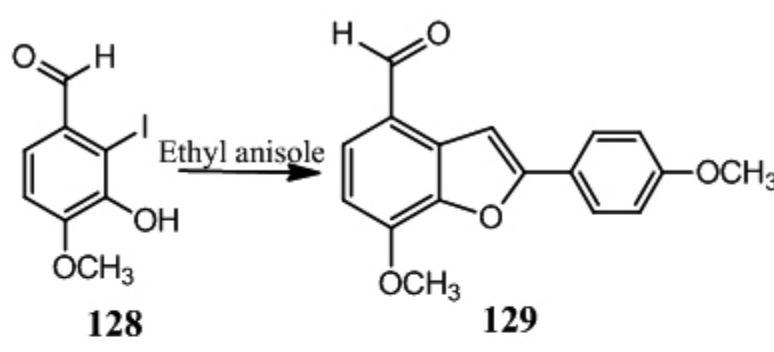

128
129 i n-bromosuccinimide,

ii. 3,5-dimethoxy

phenylboronic acid, $\mathrm{PdCl}_{2}$ iii, Phosphonate derivatives, THF, $\mathrm{NaH}$

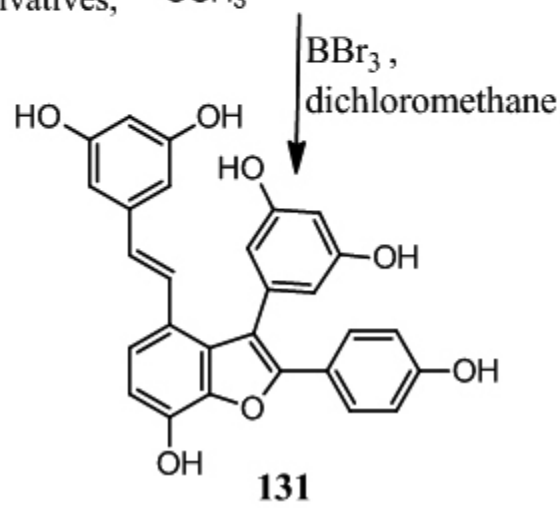

Scheme 24: Synthesis of RSV and piceatannol hybrid.

\section{CONCLUSION}

Hybrid molecules of RSV have been prepared by using the techniques like the fused hybrid and merged hybrid. In some cases, RSV was attached with other molecules via a linker group. Wittig reaction and aldol condensation reactions were used mostly to synthesize the main core of RSV. Hybridization of RSV with natural molecules such as coumarin, chalcones and caffeic acid showed antitumor activities. Anti-inflammatory activity was demonstrated by hybrid molecules of RSV with curcumin, chalcone and salicylates. Salicylates and RSV hybrid molecules also showed the inhibition of CYP1A1 and DNMT3 enzymes. RSV and vitamin E hybrid molecules exhibited antioxidan properties. Hybrid molecules of RSV with vitamin B6, clioquinol, tacrine and deferiprone displayed anti-alzheimer properties serving as potential lead molecules for treating alzheimer disease. Hybridization of RSV with biologically active heterocycles furaxon and oxadiazole produced molecules which exhibited platelet aggregation inhibition and anticancer activities.

\section{REFERENCES}

1. H. Van Poppel and B. Tombal, Cancer Manag. Res. 3, 91, (2011).

2. Altern. Med. Rev. 15, 152, (2010).

3. N. Y. Anisimova, M. V. Kiselevsky, A. V. Sosnov, S. V. Sadovnikov, I. N. Stankov and A. A. Gakh, Chem. Cent. J. 5, 88, (2011).

4. A. Koeberle and O. Werz, Drug Discovery Today 19, 1871, (2014).

5. K. A. Ahmad, N. H. Harris, A. D. Johnson, H. C. Lindvall, G. Wang and K. Ahmed, Mol. Cancer Ther. 6, 1006, (2007).

6. J. A. Baur and D. A. Sinclair, Nat. Rev. Drug Discov. 5, 493, (2006).

7. S. Das and D. K. Das, Recent Pat. Cardiovasc. Drug Discov. 2, 133, (2007).

8. M. E. Juan, I. Alfaras and J. M. Planas, Pharmacol. Res. 65, 584, (2012).

9. M. Sengottuvelan, R. Senthilkumar and N. Nalini, Biochim Biophys Acta 1760, 1175, (2006).

10. H. Gwak, G. Haegeman, B. K. Tsang and Y. S. Song, Mol. Carcinog. 54, $1529,(2015)$

11. E. Scott, W. P. Steward, A. J. Gescher and K. Brown, Mol. Nutr. Food Res. 56, 7, (2012).

12. J. Tome-Carneiro, M. Larrosa, A. Gonzalez-Sarrias, F. A. TomasBarberan, M. T. Garcia-Conesa and J. C. Espin, Curr. Pharm. Des. 19, 6064, (2013)

13. T. Walle, Ann. N.Y. Acad. Sci. 1215, 9, (2011).

14. F. Belluti, G. Fontana, L. Dal Bo, N. Carenini, C. Giommarelli and F. Zunino, Bioorg. Med. Chem. 18, 3543, (2010).
15. B. Meunier, Acc. Chem. Res. 41, 69, (2007).

16. J. R. Morphy, Designing Multi-Target Drugs, 141, (2012).

17. M. J. Matos, F. Mura, S. Vazquez-Rodriguez, F. Borges, L. Santana, E. Uriarte and C. Olea-Azar, Molecules 20, 3290, (2015).

18. W. Shen, J. Mao, J. Sun, M. Sun and C. Zhang, Med. Chem. Res. 22, 1630, (2013).

19. O. Gia, S. M. Magno, H. Gonzalez-Diaz, E. Quezada, L. Santana, E. Uriarte and L. Dalla Via, Biorg. Med. Chem. 13, 809, (2005).

20. S. Vilar, E. Quezada, L. Santana, E. Uriarte, M. Yánez, N. Fraiz, C. Alcaide, E. Cano and F. Orallo, Bioorg. Med. Chem. Lett. 16, 257, (2006).

21. X.-F. Huang, B.-F. Ruan, X.-T. Wang, C. Xu, H.-M. Ge, H.-L. Zhu and R.-X. Tan, Eur. J. Med. Chem. 42, 263, (2007).

22. J. Pan, T. Xu, F. Xu, Y. Zhang, Z. Liu, W. Chen, W. Fu, Y. Dai, Y. Zhao and J. Feng, Eur. J. Med. Chem. 125, 478, (2017).

23. D. Kumar, K. K. Raj, S. V. Malhotra and D. S. Rawat, MedChemComm 5, $528,(2014)$.

24. W. Chen, X. Ge, F. Xu, Y. Zhang, Z. Liu, J. Pan, J. Song, Y. Dai, J. Zhou, J. Feng and G. Liang, Bioorg. Med. Chem. Lett. 25, 2998, (2015).

25. L. Al-Riyami, M. A. Pineda, J. Rzepecka, J. K. Huggan, A. I. Khalaf, C. J. Suckling, F. J. Scott, D. T. Rodgers, M. M. Harnett and W. Harnett, J. Med. Chem. 56, 9982, (2013).

26. S. Li, W. Zhang, Y. Yang, T. Ma, J. Guo, S. Wang, W. Yu and L. Kong, Eur. J. Med. Chem. 124, 1006, (2016).

27. F. S. Aldawsari, O. H. Elshenawy, M. A. El Gendy, R. Aguayo-Ortiz, S Baksh, A. O. El-Kadi and C. A. Velázquez-Martínez, J. Enzyme Inhib. Med. Chem. 30, 884, (2015).

28. F. S. Aldawsari, R. Aguayo-Ortiz, K. Kapilashrami, J. Yoo, M. Luo, J. L. Medina-Franco and C. A. Velázquez-Martínez, J. Enzyme Inhib. Med. Chem. 31, 695, (2016).

29. F. S. Aldawsari, R. P. Aguiar, L. A. M. Wiirzler, R. Aguayo-Ortiz, N Aljuhani, R. K. N. Cuman, J. L. Medina-Franco, A. G. Siraki and C. A. Velázquez-Martínez, Bioorg. Med. Chem. Lett. 26, 1411, (2016).

30. X. Yang, X. Qiang, Y. Li, L. Luo, R. Xu, Y. Zheng, Z. Cao, Z. Tan and Y. Deng, Bioorg. Chem. 71, 305, (2017).

31. J. Yang, G. Y. Liu, D. L. Lu, F. Dai, Y. P. Qian, X. L. Jin and B. Zhou, Chemistry-A European Journal 16, 12808, (2010).

32. L. A. Dutra, J. F. O. Guanaes, N. Johmann, M. E. L. Pires, C. M. Chin, S. Marcondes and J. L. Dos Santos, Bioorg. Med. Chem. Lett. 27, 2450, (2017).

33. M. Murty, R. Penthala, S. Polepalli and N. Jain, Med. Chem. Res. 25, 627, (2016).

34. J. Jeřábek, E. Uliassi, L. Guidotti, J. Korábečný, O. Soukup, V. Sepsova, 
M. Hrabinova, K. Kuča, M. Bartolini and L. E. Pena-Altamira, Eur. J. Med. Chem. 127, 250, (2017).

35. F. Mao, J. Yan, J. Li, X. Jia, H. Miao, Y. Sun, L. Huang and X. Li, Org. Biomol. Chem. 12, 5936, (2014).

36. C. Lu, Y. Guo, J. Yan, Z. Luo, H.-B. Luo, M. Yan, L. Huang and X. Li, J. Med. Chem. 56, 5843, (2013).

37. P. Xu, M. Zhang, R. Sheng and Y. Ma, Eur. J. Med. Chem. 127, 174, (2017).
38. A. Kamal, M. Ashraf, S. T. Basha, S. A. Hussaini, S. Singh, M. Vishnuvardhan, B. Kiran and B. Sridhar, Org. Biomol. Chem. 14, 1382 , (2016).

39 S. Park, J. K. Seok, J. Y. Kwak, Y.-H. Choi, S. S. Hong, H.-J. Suh, W. Park and Y. C. Boo, Archives of dermatological research 308, 325, (2016).

40. N. A. Markina, Y. Chen and R. C. Larock, Tetrahedron 69, 2701, (2013).

41. D. D. Vo and M. Elofsson, Adv. Synth. Catal. 358, 4085, (2016). 